\title{
Aboveground litter production and bioelement potential return in an evergreen oak (Quercus rotundifolia) woodland near Salamanca (Spain)
}

\author{
A Martín 1 , JF Gallardo2*, I Santa Regina² \\ ${ }^{1}$ Area de Edafología, Universidad de Salamanca, Salamanca 37080; \\ ${ }^{2}$ IRNAICSIC, Apdo 257, Salamanca 37071, Spain
}

(Received 6 February 1995; accepted 20 June 1995)

\begin{abstract}
Summary - Total aboveground production of trees has been determined in a Quercus rotundifolia evergreen oak woodland developed over a chromic Luvisol. The woodland is located close to the city of Salamanca (central-western Spain). Litter fall occurs throughout the year, with a maximum from April to June owing to leaf fall. Mean litter production is $1.9 \mathrm{Mg} \mathrm{ha}^{-1}$ year ${ }^{-1}$, although variations from year to year are observed, mostly due to water stress in summer. The mean area of influence of litter fall of each tree is about $4 \mathrm{~m}$ outside the crown shadow and the leaf percentage $(55 \%)$ over the total aboveground litter production shows that the system is mature. Tree inflorescences are found to have the highest concentration in bioelements, although the latter are mostly returned through the leaves (with the exception of $K$ ).
\end{abstract}

biogeochemical cycles / litter fall / evergreen oak / Quercus rotundifolia Lam / potential return of bioelements

Résumé - Production de litière et restitution au sol de bioéléments dans une chênaie (Quercus rotundifolia) près de Salamanque (Espagne). On a déterminé la production de litière dans une chênaie à Quercus rotundifolia développée sur un Luvisol chromique dans les environs de Salamanque (ouest de l'Espagne). La chute de litière s'étaie sur toute l'année, avec un maximum dans la période avril-juin, principale époque de retombée des feuilles. La production moyenne de litière est de $1.9 \mathrm{Mg} \mathrm{ha}{ }^{-1} \mathrm{an}^{-1}$, avec des variations interannuelles dues au stress hydrique pendant l'été. Dans cette chênaie claire ("dehesa ") arrivée à maturité, l'influence de l'arbre s'étend jusqu'à une distance de $4 \mathrm{~m}$ à partir de la base du tronc. Les inflorescences sont, en général, les organes ayant les plus fortes teneurs relatives en bioéléments. Mais le plus grand retour potentiel des bioéléments se fait par l'intermédiaire des feuilles (excepté pour $K$, qui retourne plutôt avec les inflorescences).

cycle biogéochimique / chute de litière / chênaie / Quercus rotundifolia Lam / restitution des nutriments au sol

\footnotetext{
${ }^{*}$ Correspondence and reprints
} 


\section{INTRODUCTION}

The biogeochemical cycle of organic matter and mineral elements is the main aspect of the relationships between soil and vegetation and thus is an essential ecological phenomenon in natural biocenosis, in particular in forest populations (Rapp, 1969).

In a forest ecosystem, in general, annual plant production is mainly reflected in a massive contribution of dead organic matter, which accumulated on the soil (Mangenot and Toutain, 1980). The litter accumulated on the ground, together with the residual organic matter coming from the root decomposition, is the essential source of energy, C, N, K, P and other bioelements for the microflora and mesofauna of the soil (McClaugherty et al, 1982), as well as an amount of nutrients readily available and reutilizable by the plant cover (Rapp and Leonardi, 1988).

In ecosystems located on 'dehesa' hilly areas (low tree density ecosystems and wide open spaces populated with herbaceous species; Escudero et al, 1985), the tree covering also exerts a considerable influence on soil properties (Escudero and Garcia, 1986). Owing to the separation of one tree from the other, this influence is reflected in great spatial heterogeneity in soil composition (Escudero, 1983) due both to the differences in the amounts of detritus reaching the soil and to greater susceptibility to decomposition in open areas. Nevertheless, Santa Regina et al (1989) did not find significant differences in the litter decomposition below trees in relation to open areas.

The aim of the present work was to quantify and determine the temporal and spatial distribution of the litter fall in evergreen oaks and to determine the potential return of bioelements to the soil and the relationship between this return and the concentration of bioelements in the upper soil horizons of the woodland studied.

\section{MATERIALS AND METHODS}

A 1 ha experimental plot located at $840 \mathrm{~m}$ asl, 11 $\mathrm{km}$ to the west of the city of Salamanca at the Muñovela experimental farm (CSIC) was chosen for this study. The plot is edaphically homogeneous, with a dehesa-like woodland. Previously it was heavily grazed although it is now fenced off to prevent the access of domestic animals.

The climate of the zone features rainy winters and hot summers and may be classified as semiarid Mediterranean. Long-term mean rainfall and temperature have mean values of $500 \mathrm{~mm}$ year $^{-1}$ and $10.8^{\circ} \mathrm{C}$, respectively, although the means of the 3 years of the study period were $370 \mathrm{~mm}^{-}$year ${ }^{-1}$ and $11.5^{\circ} \mathrm{C}$, October being the rainiest month $(83.8 \mathrm{~mm})$ and July the driest $(12.7 \mathrm{~mm})$. January is normally the coldest month $\left(2.0^{\circ} \mathrm{C}\right)$ and July the hottest $\left(22.0^{\circ} \mathrm{C}\right)$.

The tree covering comprises Quercus rotundifolia Lam, with a density of 98 trees $\mathrm{ha}^{-1}$, a mean height of $5.9 \mathrm{~m}$ and a mean diameter of $29.1 \mathrm{~cm}$.

The soil is a chromic Luvisol, developed over red clays and Miocene conglomerates. The slope of the plot is $5 \%$.

Determination of the litter production was performed by placing 30 collecting boxes of $0.24 \mathrm{~m}^{2}$ of surface area distributed according to a network arrangement (five series) and occupying a surface of $2050 \mathrm{~m}^{2}$. The amount of litter fallen into the boxes was collected at approximately monthly intervals and separated into individual components (leaves, branches, inflorescences, fruit and others), weighing each after drying at $80^{\circ} \mathrm{C}$. The following methods were used for chemical analysis of the different litter components: total $\mathrm{C}$, dry combustion with a Carmhograph 12 Wösthoff; total $\mathrm{N}$ with a Heraeus Macro- $\mathrm{N}$ analyzer; $\mathrm{P}$ by colorimetry using the vanadomolybdophoshoric yellow colorimetric method (spectrophotometer Varian DMS 90); $\mathrm{Ca}, \mathrm{Mg}, \mathrm{Mn}, \mathrm{Fe}, \mathrm{Cu}$ and $\mathrm{Zn}$ by atomic absorption spectrophotometry (Varian 1475); $\mathrm{K}$ and $\mathrm{Na}$ by flame photometry (Varian 1475).

The soil samples were taken from the horizon of a soil profile where the edaphic morphologies had been previously described. Analytical determinations of the soils were as follows: organic $\mathrm{C}$ by the wet method according to the potassium dichromate method; total $\mathrm{N}$ with a Heraeus Macro- $\mathrm{N}$ analyzer; assimilable $\mathrm{Ca}, \mathrm{Mg}$ and $\mathrm{K}$ by extraction with $1 \mathrm{~N}$ ammonium acetate $(\mathrm{pH} 7.0)$; assimilable $\mathrm{P}$ according to the method of Bray- 
Kurtz (1945); cation exchange capacity according to the method of Black et al (1965). Exchange cations were extracted following the ammonium acetate ( $\mathrm{pH} 7.0)$ method and analyzed by atomic absorption spectrophotometry (Varian 1475). In general, samples were analyzed by duplicate, in some cases by triplicate. For the transformation of initial $\mathrm{g} \mathrm{kg}^{-1}$ to $\mathrm{kg} \mathrm{ha}^{-1}$, the soil horizon depths, bulk density and stoniness were previously known; the Ah epipedon refers to a depth of $20 \mathrm{~cm}$.

\section{RESULTS AND DISCUSSION}

The initial data available correspond to three annual cycles (March 1990-March 1993) with respect to the contribution of tree remains (dry matter) to the soil and to only two cycles (March 1990-March 1992) as regards chemical composition. Results are shown in tables I to IV.

\section{Contribution of detritic matter, temporal and spatial distribution}

As reported earlier, the study was performed on a dehesa-like woodland and hence there are open areas. In this plot, the crowns of the trees occupy a surface area of $3070 \mathrm{~m}^{2} \mathrm{ha}^{-1}$ and thus $70 \%$ of the surface is clear (temporal pasture), although the influence of the trees extends to a greater surface area than that corresponding to the crowns. To determine this influence, the (positive) distance from each box to the edge of the crown of the closest tree was determined, assuming that the

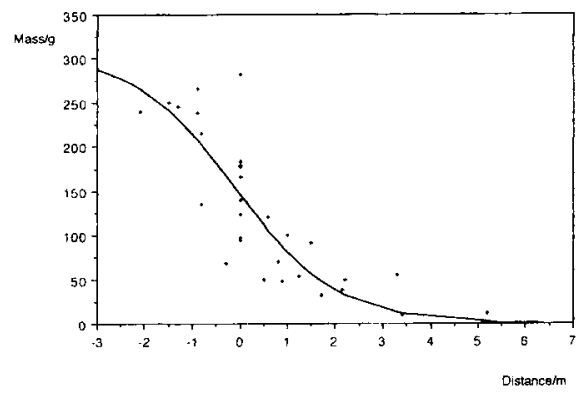

Fig 1. Relation between litter fall mass and the distance from the tree border $(=0)$.

distances are negative when the boxes were under the crowns. On representing the production per box for the three cycles against the distance to the crown of the closest tree, production was seen to be high below the crown and to decrease progressively as the distance from this increases (fig 1). On fitting these findings to some kind of curve (exponential, linear, etc), the best result was obtained by a nonlinear regression, according to the expression:

$$
\text { weight } \left.(g)=-\overline{-}^{308}-\overline{\left(1.11^{\text {distance }}\right.}\right)
$$

indicating that for large distances (in $\mathrm{m}$ ) production tends towards zero while under the crown it tends towards a constant value. From this equation it can be deduced that all the boxes situated at a distance greater than $4 \mathrm{~m}$ from the edge of a crown

Table I. Litter production of Quercus rotundifolia woodland and partial percentage of different litter fractions.

\begin{tabular}{cccccccc}
\hline Production & Year & Leaves & Branches & Flowers & Fruits & Others & Total \\
\hline kg ha $^{-1}$ year $^{-1}$ & $1990-1991$ & 1072 & 250 & 351 & 388 & 78 & 2139 \\
& $1991-1992$ & 1076 & 216 & 515 & 158 & 82 & 2048 \\
& $1992-1993$ & 926 & 282 & 137 & 91 & 37 & 1474 \\
& Mean & 1025 & 250 & 335 & 212 & 66 & 1887 \\
\hline$\%$ & $1990-1991$ & 50.1 & 11.7 & 16.4 & 18.1 & 3.6 & 100 \\
& $1991-1992$ & 52.5 & 10.6 & 25.2 & 7.7 & 4.0 & 100 \\
& $1992-1993$ & 62.8 & 19.2 & 9.3 & 6.2 & 2.5 & 100 \\
& Mean & 55.2 & 13.8 & 17.0 & 10.7 & 3.4 & 100 \\
\hline
\end{tabular}



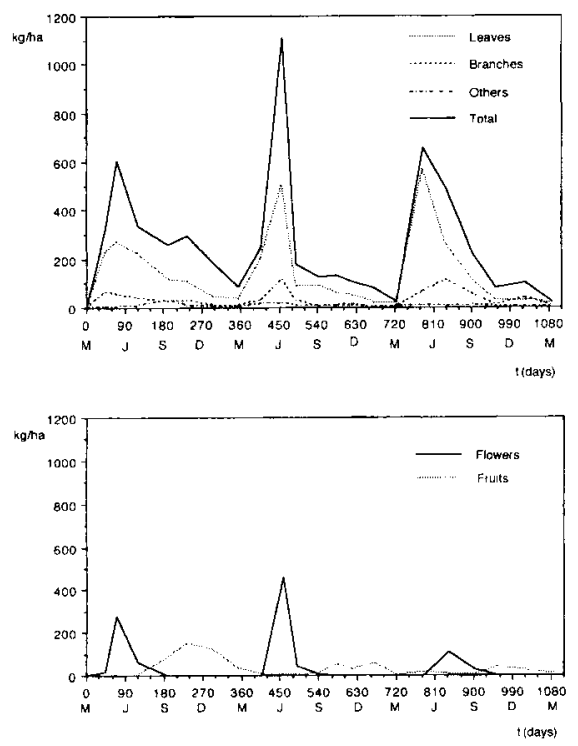

Fig 2. Temporal variation of different litter fall fractions (start date: 26 March 1990). M: March; J: June; S: September; D: December.

would collect less than $5 \%$ of the mean production per box and can therefore be considered as representative of a zone unaffected by the trees. On this plot, these zones are almost absent. Accordingly, on calculating the fall of litter per hectare, all the boxes were considered to be representative of the woodland.

Table I shows the annual production values obtained for the different fractions together with the percentages that these represent in the whole set of litter. The importance of having knowledge of the amounts of each of these fractions is evident since the return of elements to the soil will follow different recycling patterns, which may overlap in space and time.

As in the case of most forest systems, the leaves comprise the most important fraction $\left(1.0 \mathrm{Mg} \mathrm{ha}^{-1}\right)$, representing $55 \%$ of the total contribution (table I); according to Kira and Shidei (1967), this reflects the state of maturity of the forest.
In this species, leaf fall occurs throughout the year, although a maximum can be seen in the April-June period (fig 2), which to a large extent governs the temporal patterns of the return of litter to the soil.

Inflorescences occupy the second most important place in the amount contributed to the soil, within the whole set of litter components (335 kg ha-1) and represent the most homogeneous annual response (fig 2); a sharp peak appears in June, as reported by Gómez et al (1980).

Branch fall can be said to be intimately linked to that of the leaves (fig 2), although the contribution of the latter is smaller and only represents $14 \%$ of the total (table I).

The fraction corresponding to the fruit displays a period of maximum return corresponding to the October-January period. This fraction represents $11 \%$ of the total, a figure similar to that recorded in the Montseny mountains oak grove (Ferrés et al, 1984).

It may be seen that during the third year, litter production decreased by $30 \%$ with respect to the 2 preceding years (1.5 vs 2.1 $\left.\mathrm{Mg} \mathrm{ha}^{-1}\right)$. This decrease is probably a reflection of the prevailing climatic conditions during those years since, if 1990 was considered a dry year $(411 \mathrm{~mm}), 1991$ and 1992 were even drier $(340$ and $350 \mathrm{~mm}$, respectively) and hence the vegetation was subjected to water stress after 3 consecutive years of drought; this would have affected the production of all their organs. On the other hand, a relative increase of leaves in relation to the aboveground production was observed ( $63 \%$ vs 50 and $53 \%$ ), because of the lower total production. Branches had also an increase in 1992-1993 (table I).

Unlike what has been reported by other authors (Rapp, 1969, 1971; Gómez et al, 1980; Hernández et al,1992a), this woodland does not display a biannual pattern in the litter production, perhaps because the above-mentioned drought would have led to a reduction in the availability of nutrients during the hot season (Ferrés et al,1984) 
Table II. Mean annual nutrient concentrations (weighted annual mean concentrations) of litter fall components $\left(\mathrm{mg} \mathrm{g}^{-1}\right)$.

\begin{tabular}{lcrrrrrrrrrc}
\hline Fraction & $C$ & $N$ & $C a$ & $M g$ & $P$ & $K$ & $N a$ & $M n$ & $F e$ & $C u$ & $Z n$ \\
\hline Leaves & 485 & 10.0 & 10.2 & 1.2 & 0.6 & 2.8 & 0.16 & 0.56 & 0.12 & 0.01 & 0.02 \\
Branches & 472 & 9.2 & 13.2 & 1.3 & 0.7 & 4.0 & 0.15 & 0.28 & 0.14 & 0.01 & 0.02 \\
Flowers & 494 & 16.5 & 4.8 & 1.4 & 1.4 & 13.1 & 0.17 & 0.36 & 0.09 & 0.01 & 0.01 \\
Fruits & 471 & 9.4 & 3.0 & 0.8 & 0.7 & 6.1 & 0.16 & 0.18 & 0.03 & 0.01 & 0.01 \\
Others & 453 & 16.3 & 5.0 & 1.7 & 1.9 & 4.0 & 0.15 & 0.20 & 0.15 & 0.01 & 0.03 \\
\hline
\end{tabular}

and in the number of leaves. This would have caused the tree covering to make use of nutrients stored in the wood, together with those stored in the leaves of previous years and would have resulted in an alteration in the rhythm of production. Alternatively, it could have been due to some genetic effect of the different subspecies existing in the dehesa-like woodlands (Jiménez et al,1994).

\section{Annual potential return of bioelements to the soil}

With a knowledge of the annual production of litter (table I) and its mean composition (table II), it is possible to calculate the maximum amount of bioelements that would potentially be able to return from the trees to the soil over two annual cycles (March 1990-March 1992).

The values for the mean potential return are expressed in table III.

It should be noted that the differences of annual potential return of bioelements between years are mainly due to the different productions of organs, especially inflorescences and fruits during the 2 years (table I), the differences being minimum as regards the mean compositions obtained for all the fractions during the 2 years. Thus, the soil of this plot (table III) received a mean potential contribution of $24,18,12,3$ and $2 \mathrm{~kg} \mathrm{ha}^{-1}$ year $^{-1}$ of $\mathrm{N}, \mathrm{Ca}, \mathrm{K}, \mathrm{Mg}$ and $\mathrm{P}$ (respectively), to which must be added 0.9 , 0.3 and $0.2 \mathrm{~kg} \mathrm{ha}^{-1}$ year $^{-1}$ of $\mathrm{Mn}, \mathrm{Na}$ and $\mathrm{Fe}$ (respectively). These values are similar to those reported by Gallardo et al (1992) and approximately half those found by Rapp (1971) and Ferrés et al (1984).

The leaf organs are the main vector of the potential return (table III) of all the bioelements (with the exception of $K$ ) to the holorganic horizon, followed in order of importance by the inflorescences owing to both their high level of production and their high concentration in major elements (above all $\mathrm{N}, \mathrm{Mg}, \mathrm{P}$ and $\mathrm{K}$ ). $\mathrm{K}$ is returned to the soil mainly through the inflorescences, owing to its high concentrations (table II) in these organs (13 $\mathrm{mg} \mathrm{g}^{-1}$ ).

The low contribution of the branches to the total return of practically all the bioelements should be noted. In this respect, $\mathrm{Ca}$ ( $3 \mathrm{~kg} \mathrm{ha}^{-1}$ year $^{-1}$ ), with a value close to that reported by Tamm (1951) and Gallardo et al (1992), is of interest owing to its high relative concentration $\left(13 \mathrm{mg} \mathrm{g}^{-1}\right)$ in branches.

Of the four oligoelements considered, only $\mathrm{Mn}$ is of any relevance (table III), and for all four the leaves are the organs contributing the highest quantities.

\section{Influence on the humic soil horizon}

Table IV offers the most important physicochemical and biochemical characteristics of the typical soil profile located inside the woodland experimental plot; variability of those soil parameters is nonsignificant in relation to the proposed objectives. 

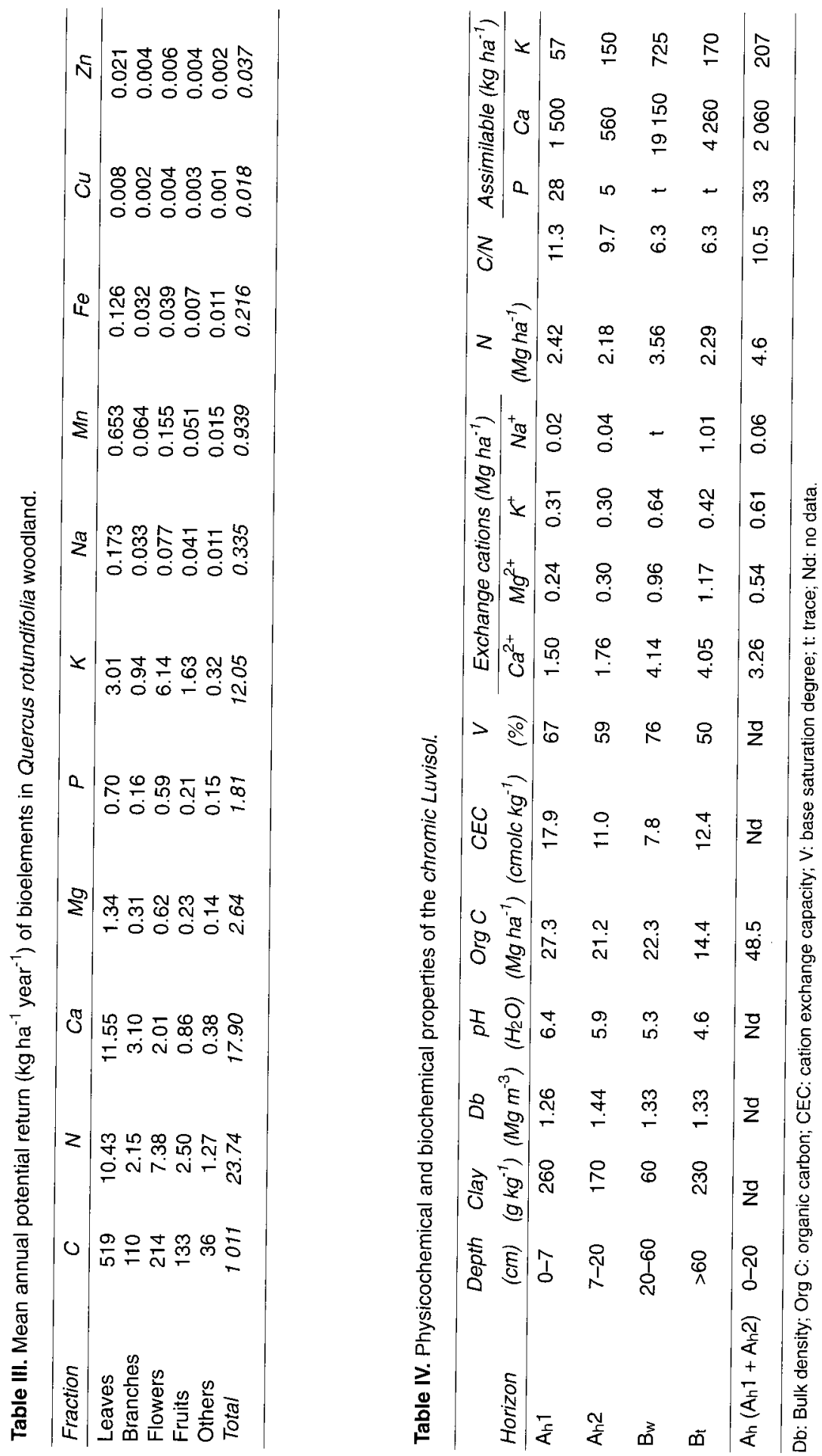
A moderately high organic $\mathrm{C}$ content (near $50 \mathrm{Mg} \mathrm{ha}^{-1}$ ) is seen in the $A_{h}$ epipedon, although this falls in lower horizons. This quantity contrasts with the annual return of $1 \mathrm{Mg} \mathrm{ha}^{-1}$ year $^{-1}$ of $\mathrm{C}$ (table III), that shows that there is an adequate humification process. Hernández et al (1992b) found that the decomposition constant in an evergreen oak woodland was 0.5 the first year, that is, half of the litter fall is decomposed in the first year. Thus, nearly 0.5 $\mathrm{Mg} \mathrm{ha}^{-1}$ of organic $\mathrm{C}$ could be yearly incorporated in the soil.

Total $\mathrm{N}$ is relatively high at the $A_{h}$ epipedon (4.6 Mg ha-1); this amount is 20 times the content returned yearly with the litterfall (24 kg ha-1 year-1; table III). Hernández et al (1995) found that the oak litter did not yield any inorganic $\mathrm{N}$ in the first year, and only $2 \mathrm{~kg} \mathrm{ha}^{-1}$ in the second year; this fact means that the inorganic $\mathrm{N}$ comes mainly from the mineralization of the soil organic $\mathrm{N}$ (assuming a mineralization constant of $1 \%$, about $45 \mathrm{~kg} \mathrm{ha}^{-1}$ year $^{-1}$ of inorganic $\mathrm{N}$ are liberated, enough for the needs of the oak forests; Rapp, 1971; Ferrés et al, 1984).

The humus can be considered as acid mull (mean $\mathrm{C} / \mathrm{N}$ ratio is 10.5 in the $\mathrm{A}_{\mathrm{h}}$ epipedon), since humification is only limited by summer dryness (Martín et al, 1994) because of the moderately acid $\mathrm{pH}$ values at the surface (favoring the bacterial activity; Dommergues and Mangenot, 1970) and the relatively high content of $\mathrm{N}$ of the readily decomposable inflorescences (Escudero et al,1985); decomposition of this material is also favored in the open spaces (Escudero and García, 1986).

In the same way as $N$, litter $P$ is mineralized very slowly $\left(0.2 \mathrm{~kg} \mathrm{ha}^{-1}\right.$ the first year and $0.4 \mathrm{~kg} \mathrm{ha}^{-1}$ the second, according to Hernández et al,1995); futhermore, the $P$ returned yearly $\left(2 \mathrm{~kg} \mathrm{ha}^{-1}\right)$ is very low in comparison with the soil assimilable $P$ in the $A_{h}$ epipedon (33 $\mathrm{kg} \mathrm{ha}^{-1}$ ).

As observed in table IV, assimilable $\mathrm{Ca}$ and $\mathrm{K}$ gave, in general, different figures than exchangeable $\mathrm{Ca}$ and $\mathrm{K}$, because the extraction procedures were different (it is not possible to give more details in this work). In any case, the $\mathrm{Ca}$ returned yearly (18 $\mathrm{kg} \mathrm{ha}^{-1}$; table III) is too low in comparison to the soil assimilable $\mathrm{Ca}$ in the $A_{h}$ epipedon ( $\left.2 \mathrm{Mg} \mathrm{ha}^{-1}\right)$; in contrast, the $\mathrm{K}$ returned yearly $\left(18 \mathrm{~kg} \mathrm{ha}^{-1}\right.$, mostly in soluble form; Hernández et al, 1995) is a significant quantity in comparison with the soil assimilable $\mathrm{K}\left(207 \mathrm{~kg} \mathrm{ha}^{-1}\right)$.

The total cation exchange capacity is moderately high, and the degree of saturation of the cation exchange capacity varies from horizon to horizon but it is always greater than $50 \%$; this is mainly governed by the climatic factor (restricted leaching; table IV).

Finally, the biogeochemical cycle is seen to be efficient with respect to assimilable bioelements, at least in the case of $P$ (which passes from $33 \mathrm{~kg} \mathrm{ha}^{-1}$ in the $A_{h}$ horizon to almost zero at lower depths), due to the recycling of the organic materials (leaves and inflorescences) that contribute the greatest quantities of this bioelement to the soil substrate.

\section{CONCLUSION}

i) Litter fall in this dehesa woodland occurs throughout the year, although it displays a maximum in the period covering AprilJune, owing to the fall of the leaves (the most abundant organs) and undergoes between-year variations as a result of water stress.

ii) The influence of the trees extends up to a distance of $4 \mathrm{~m}$ away from the edge of the crowns; density is sufficient to ensure that no spaces remain outside the influence of the tree covering.

iii) The dehesa-like woodland is mature, the leaves reaching $55 \%$ of the total contribution of the annual litter.

iv) The leaves are the organs that contribute most to the return of bioelements of the soil, followed by the inflorescences (rela- 
tively richer in bioelements); the contribution of $\mathrm{Ca}$ by the branches is also important. v) The degree of saturation of bases seems to be affected by climatic conditions (restricted leaching), whereas the content of assimilable bioelements in the soil surface is affected by both the litter return and the mineralization rate.

\section{ACKNOWLEDGMENTS}

Economical support was received from the AIR and STEP Programs (DG XII/EU), from the DGCYT/SEUI $\left(M^{\circ} E C\right)$ and from the 'Junta de Castilla y León'. Technical aids from ML Cosme, MC Macarro, C Perez and C Relaño are grateful. The English version has been revised by N Skinner.

\section{REFERENCES}

Black CA, Evans DD, White JL, Ensminger LE, Clark FE (1965) Methods of soil analysis (2 vols). American Society of Agronomy, Madison, WI, USA

Bray RH, Kurtz LT (1945) Determination of total, organic, and available forms of phosphorus in soils. Soil Sci 59, 39-45

Dommergues Y, Mangenot F (1970) Écologie microbienne du sol. Masson, Paris

Escudero A (1983) Transferencias de nutrientes minerales desde el estrato arbóreo en monte adehesado (ecosistemas de pastizales semiáridos). Doctoral Thesis, Universidad de Salamanca, Spain

Escudero A, García B (1986) Variaciones espaciales de la composición química del mantillo arbóreo en el ecosistema de dehesa. Anu Cent Edaf Biol Apli Salamanca 11, 325-336

Escudero A, García B, Gómez JM, Luis E (1985) The nutrient cycling in Quercus rotundifolia and Quercus pyrenaica ecosystems ('dehesas') of Spain. Acta Oecol, Oecol Plant 6, 73-86

Ferrés LI, Rodá F, Verdú AMC, Terradas J (1984) Circulación de nutrientes en algunos ecosistemas forestales del Montseny (Barcelona). Mediterranea Ser Biol 7, 139-166

Gallardo JF, Hernández IM, Santa Regina I (1992) Retorno potencial al suelo de bioelementos por medio de la hojarasca en bosques bajo clima semiárido de la Cuenca del Duero. III Congreso Nacional de la Ciencia del Suelo, Pamplona, Spain, 633-638
Gómez JM, Luis E, Escudero A (1980) Materiales aportados al suelo por la encina en la zona de dehesas salmantina. I. Sustancia seca. Stvdia Oecol 2, 181211

Hernández IM, Gallardo JF, Santa Regina I (1992a) Dynamic of organic matter in forests subject to a mediterranean semi-arid climate in the Duero basin (Spain): litter production. Acta Oecol 13, 55-65

Hernández IM, Santa Regina I, Gallardo JF (†992b) Dinámica de la descomposición de la hojarasca forestal en bosques de la Cuenca del Duero: modelización de la pérdida de peso. Arid Soil Res Rehabil $6,339-355$

Hernández IM, Santa Regina I, Gallardo JF (1995) Dynamic of bioelements in leaf decomposition in three forest ecosystems of semiarid climate in the Duero Basin. Arid Soil Res Rehabil 9, 437-455

Jiménez P, Díaz-Fernández PM, Gil LA(1994) Regiones de procedencia de Quercus ilex $L$ en España. III Congresso Florestal Nacional. Sociedade Portuguesa de Ciências Florestais, Lisbon, Portugal, 1, $397-405$

Kira T, Shidei T (1967) Primary production and turnover of organic matter in different forest ecosystems of the Western Pacific. Jpn J Ecol 17, 70-87

McClaugherty CA, Aber JD, Melillo JN (1982) The role of fine roots in the organic matter and nitrogen budgets of two forested ecosystems. Ecology 63, 14811490

Mangenot $F$, Toutain F (1980) Les litières. In: Actualités d'écologie forestière (P Pesson, ed), Gauthier-Villars, Paris, 3-69

Martín A, Rapp M, Santa Regina I, Gallardo JF (1994) Leaf litter decomposition dynamics in some mediterranean deciduous oaks. Eur J Soil Biol 30, 119-124

Rapp M (1969) Production de litière et apport au sol d'éléments minéraux dans deux écosystèmes méditerranéens : la forêt de Quercus ilex L et la garrigue de Quercus coccifera L. Oecol Plant 4, 377-410

Rapp M (1971) Cycle de la matière organique et des éléments minéraux dans quelques écosystèmes méditerranéens. CNRS, Paris

Rapp M, Leonardi S (1988) Évolution de la litière au cours d'une année dans un taillis de chêne vert (Quercus ilex). Pedobiology 32, 177-185

Santa Regina I, Gallardo JF, San Miguel C (1989) Ciclos biogeoquímicos en bosques de la Sierra de Béjar (Salamanca, España). 3. Descomposición de la hojarasca. Rev Ecol Biol Sol 26, 407-416

Tamm CO (1951) Seasonal variation in composition of birch leaves. Physiol Plant 4, 461-469 